\title{
Defining "Development"
}

\section{Thomas Pradeu, Lucie Laplane, Karine Prévot, Thierry Hoquet, Valentine Reynaud, Giuseppe Fusco, Alessandro Minelli, Virginie Orgogozo, Michel Vervoort}

\section{To appear in a special anniversary issue of Current Topics in Development Biology, edited by Paul Wassarman}

"one cannot present a science without at the same time defining its terms" (Leibniz, New Essays on Human Understanding)

"Insistence on the postulate of complete logical clarification would make science impossible" (Heisenberg, Physics and Philosophy)

\begin{abstract}
Is it possible, and in the first place is it even desirable, to define what "development" means, and to determine the scope of the field called "developmental biology"? Though these questions appeared crucial for the founders of "developmental biology" in the 1950s, there seems to be no consensus today about the need to address them. Here, in a combined biological, philosophical, and historical approach, we ask whether it is possible and useful to define biological development, and, if such a definition is indeed possible and useful, which definition(s) can be considered as the most satisfactory.
\end{abstract}

\section{Keywords}

Development; embryology; developmental biology; scientific discipline; definition.

\section{Introduction}

How can we define "development"? And, in the first place, why should anyone care about a definition of development? Despite the existence of a well-established and dynamic scientific field called "developmental biology", those two questions are hardly ever raised today (Minelli and Pradeu 2014). Etymologically, "development" means "unfolding", that is, the progressive unfolding of a preexistent form or preexistent capacities. But very few would endorse today this form of preformationism, which neglects interactions with the environment and stochastic effects (Lewontin 2000).

In recent years, only a handful of developmental biologists have ventured to define "development" in research papers or books (exceptions include Coen 1999 and Davidson 2001), and definitions of development are found mainly in textbooks. A frequent textbook definition is "the process through which a single cell - often a fertilized egg - gives rise to a complex multicellular organism" (Wolpert and Tickle 2011; see also Slack 1991; MartinezArias and Stewart 2002). Yet this definition has sometimes been criticized for its "adultocentrism" (Bonner 1965; Minelli 2003), and the exclusion of unicellular organisms, many forms of asexual reproduction where development starts from a multicellular stage, as well as the phenomena of regeneration and ageing. Others have suggested to define development as all the changes that occur in a given organism from its beginning to its death (e.g., Oyama 2000; West-Eberhard 2003; Gilbert 2013), a definition perhaps too broad, as it would include virtually all physiological processes (Pradeu et al. 2011). It seems, therefore, 
that many developmental biologists would agree with Guirao and Aréchaga (1989) that "the term 'development' is difficult to define", and few try to offer an explicit definition.

But should developmental biologists really care about defining development? The current research field of developmental biology offers an interesting and contrasting situation with regard to this question. In an attempt to better characterize this situation, we asked all the contributors to the present special issue of $C T D B$ the two following questions: i) Do you think that it is important, for your scientific work in developmental biology, to define the word "development"?; ii) How, according to you, should the notion of "development" be defined? Among the 24 contributors who accepted to answer our mini-survey, 13 of them (54\%) consider that they do not need a definition of development, while $11(46 \%)$ believe exactly the opposite. Moreover, these 24 contributors propose diverse definitions that disclose several points of dissension, such as whether development should include regeneration, ageing, or the idea of increasing complexity when an organism matures. Of course, the sample of our survey is far too small to draw any definitive conclusion. And yet both our survey and a careful study of past and present literature in developmental biology suggest a lack of consensus about what belongs to "development" or "developmental biology", and what does not.

The term "developmental biology" came to encompass and replace, in intellectual societies and journals, the older labels of "embryology" and "growth" (or "growth and differentiation") at the end of the 1950s (Gilbert 1991: ix; Burian and Thieffry 2000; Crowe et al. 2015). In fact, the questions of what development means and how extensive developmental biology should be were crucial for the biologists who, immediately after the Second World War, participated in the construction of the emerging discipline that came to be called "developmental biology". In the Foreword of the very first issue of the Journal of Embryology and Experimental Morphology (renamed Development in 1986), Albert M. Dalcq (1953) announces that, with the advent of "the science of development", embryologists witness "an extraordinary extension of their field", in depth (the reach of the "macromolecular level"), space (the progressive establishment of a "common denominator" of morphogenesis, regeneration, asexual reproduction, and embryonic development), and time (the gradual effacement of "the conventional boundaries between the biological phases of life", with a shift of attention from early embryonic phases only to a much broader focus on cytodifferentiation, growth, and even continuous re-construction throughout life and ageing). In a similar vein, in his Introduction to the first issue of the US journal Developmental Biology, Paul Weiss (1959) suggests that many seemingly isolated phenomena studied hitherto by embryologists, plant physiologists, nutritionists, or oncologists, constitute in fact "one continuous spectrum", unified by the "same basic principles" of growth, differentiation, morphogenesis, maturation, ageing, regulation, and regeneration, which all together constitute "development".

Because of the remarkable successes of developmental biology from the 1950s to the present day, its current practitioners do not focus as ardently as their predecessors on the question of how to define the term "development" and how to delineate its scope. Importantly, though, this question has not entirely disappeared. For example, the British Society of Developmental Biology recently considered whether its name should change to the "British Society of Developmental Biology and Stem Cells", illustrating "heated discussion in the developmental biology community about what its relationship should be to the stem cell field" (St Johnston 2015).

Thus, it appears that there was not, and there still is not, any strong consensus among developmental biologists about both the definition of development and the delineation of the domain of developmental biology. In this essay, our aim is to determine whether today's developmental biologists should, as their predecessors of the 1950s did, seek a definition and a delineation of development. More precisely, we address, in a combined biological, 
philosophical, and historical approach, the vexing problem of whether it is possible and useful to define biological development, and, if such a definition is possible and useful, which definition(s) should be used.

\section{Should we try to define development? No, we should not}

\subsection{It is useless}

As illustrated by several sharp answers to our survey, many biologists feel that attempting to define development is simply useless. Biologists are generally interested in specific empirical studies, that is, studies of precise mechanisms in a given model organism (e.g., gene expression during embryogenesis in the sea urchin, or Wnt signaling in the formation of the chick's neural crest, or auxin signaling in the formation of a plant embryo root). Therefore, it may seem that general definitions are not useful for the work that really matters, namely experimentation. If, in practice, developmental biologists can perfectly do their research without ever wondering about what development means, then why should they care?

A precise definition can even be considered as a hindrance for doing practical research in developmental biology. Most scientific concepts remain undefined, implicit, and this is not an obstacle for everyday science (Kuhn 1962). According to many historians of science, conceptual fuzziness is widespread in science, and even fruitful (Rheinberger 2000; Keller 2002). Some degree of imprecision can contribute to foster communication between scientists, both within a scientific domain and between domains. For example, Keller (2002: 181) claims that it is largely because of its malleability that the concept of positional information (Wolpert 1968) became popular and fruitful, that is, extensively used and discussed until today.

\subsection{It is impossible}

A different attitude consists in saying that defining development, as useful as it might be, is in fact impossible. In nature, developmental phenomena are so diverse that it would make no sense to pretend that one single definition could bring together all these processes. First, the word "development" can be applied to many organisms across species. Would it not be hazardous to assert that this same word might be applied to plants, microbes, and animals all alike? It seems likely that every general definition of development will inevitably meet with some exceptions (Minelli 2014). Second, it covers phenomena situated at many different levels (molecular, cellular, and so on). Third, it encompasses a series of generally successive and heterogeneous processes, such as, in animals, fertilization, cleavage, gastrulation, organogenesis and, sometimes, metamorphosis and regeneration. Faced with such a multifaceted diversity, how could developmental biologists offer one single, unifying, definition of development?

Instead of searching for the meaning of development per se, one might try to define a series of more specific terms, like "cell differentiation," "morphogenesis", and "organogenesis". For this strategy to be successful, these processes themselves need to be defined. But, to define a word, one must use other words, which themselves might prove difficult to define - a process that could lead to an infinite regress. Potential definitions of "development" are often circumlocutions involving other terms like "morphogenesis," "shape," "irreversibility," "pattern," "complexity," but generally those terms are themselves particularly difficult to define (see Table 1).

\section{Should we try to define development? Yes, we should}

\subsection{To delineate developmental biology as a field of study}


A definition of development allows to delineate the domain of developmental biology as a scientific field, that is, to determine which living things and processes should be considered as subjects of developmental studies. Now, many biologists might say that they do not care about a definition of development, but, presumably, not so many would say that defining the research field named "developmental biology" is useless. Interestingly, several people who answered our survey remark that biologists often disagree on whether certain processes - e.g., fertilization, regeneration - and certain organisms - e.g., plants - are part of developmental biology. This problem is all but marginal: clarifying what falls under the scope of "developmental biology" is crucial to compare different experimental settings and models, and to determine how each may shed light on the others. As mentioned previously, defining the scope of their field was one of the most pressing issues for the scientists involved in the advent of "developmental biology" in the 1950s. For Paul Weiss (1959), in a time of "progressive splintering of older disciplines into ever smaller and narrower technical specialties", the then emerging field of "developmental biology" aimed at doing exactly the opposite, that is, "to promote the confluence and integration of related, but formerly isolated, lines."

Two examples illustrate why this question is still very important today. The first example concerns the place of plants in developmental biology. The question of whether plants should be included in the domain of embryology was raised as early as the first half of the $19^{\text {th }}$ century (e.g., Schleiden 1848). Including or excluding plants from the study of development changes our vision of development: it questions whether development continues in adulthood (Steeves and Sussex 1989), whether regeneration is part of development (Birnbaum and Sanchez Alvarado 2008), and whether development should be defined molecularly (in which case "development" would mean two different things for plants and for animals) or rather at the level of general principles (in which case there may exist a unified meaning of development, adequate for both plants and animals) (Meyerowitz 2002; Vervoort 2014).

In a similar vein, an interesting debate today is whether unicellular organisms should be included into the study of development (O'Malley and Dupré 2007; Love and Travisano 2013), and if the term "development" means the same thing when applied to multicellular organisms only (a very common practice among developmental biologists), or to unicellular organisms as well. Though textbooks and meetings in developmental biology do not, in general, include unicellular organisms, there has existed for more than thirty years a dynamic field self-identified as "developmental microbiology" (e.g., Peberdy 1980). Furthermore, multiple observations argue for their inclusion. Several unicellular organisms, such as Acetabularia (Dumais, Serikawa and Mandoli 2000), social amoebae (Bonner 2009), and bacteria (Peberdy 1980; Kroos and Maddock 2003) can be said to "develop", in the sense that they undergo important and stereotyped morphogenetic changes during their life cycle, including morphogenesis, cellular differentiation, and intercellular signaling (Shimkets 1999; Straight and Kolter 2009). A precise definition of development should reach a verdict on whether unicellular organisms are to be included in "developmental biology", and, perhaps most importantly, this would help to determine how studies done on microbes and those done on non-microbial entities could inspire each other.

Another similar question, which we mention only briefly here, is whether the notion of development can be applied to cognition and behavior (Gottlieb 1992; Oyama, Griffiths and Gray 2001). Here again, the only way to address such a question is to offer a definition of development.

In addition, an explicit description of what belongs to developmental biology and what does not can be useful from a purely institutional point of view. To have a clear view of which journals, scientific societies, scientific meetings, funding opportunities, or academic 
positions belong to developmental biology, it is necessary to know, if only at a very general level, what development means. In line with Weiss's aim, defining development and delineating the domain of developmental biology can be useful to foster intellectual collaborations and to give rise to a feeling to belong to a shared "community", by bringing together biologists with the same type of questions or approaches, and using the same kind of vocabulary.

\subsection{For considering development within more inclusive processes}

In science, whenever you decide to study a process which involves the transformation of something, either through time or space or otherwise, you have to define this something, operationally at least, in order to trace its change. This is the case of development in the context of evolution (e.g., evolution of development), or in the context of ecology (e.g., environmentally induced developmental responses). In other words, when development is viewed from the perspective of a more inclusive process, you need to define it. Current, sometimes pragmatic, available definitions are restricted to specific developmental processes (e.g., gastrulation, or prefoliation, see section 1.2), which merely allow studying the evolutionary history of these specific processes, but do not allow investigating more general issues, as for instance the role of developmental plasticity in the wider theoretical context of evolutionary models (Fusco and Minelli 2010).

\subsection{For communication with the public and legal purposes}

Even biologists who are skeptical about the need to define development in their own specialized domain would probably agree that defining development could be important for non-biologists. First, anyone who teaches developmental biology knows that students find definitions extremely useful. Second, many political and legal debates (for example those related to abortion, assisted reproductive technologies, or the legal status of the fetus) presuppose to have clear notions of "embryo" and "development", for which politicians and judges require the help of biologists. In agreement with Maienschein (2014), we are not suggesting here that our ethical conceptions should be based on biological data, but rather that legal decisions should not be in direct conflict with established scientific knowledge, and that, if developmental biologists could provide a clear definition of development and related notions, this would facilitate scientifically informed law making.

\subsection{To overcome implicit meanings}

Even when left undefined, a concept like "development" often has an implicit meaning, generally rooted in a common background (acquired through education and lab practices) or in intuitions, rather than cautious scientific considerations. Developmental biologists who say that they do not have, and do not need, a definition of development actually do have in mind implicit conceptions of development, which can bias their views and have negative effects on research and discoveries. For example, the idea that development is intrinsically a construction, and not destruction, almost certainly slowed down research on the role of apoptosis in development (Saunders 1966; Baehrecke 2002). Another telling example concerns the influence of genes on development. That genes play a key role in development is beyond doubt, and an impressive achievement of developmental biology from the 1950s to the present day has been the detailed molecular description of how developmental genes work (Wolpert 1994; Gilbert 1998). That being said, the long-prevailing view that development is to a large extent "autonomous" with regard to the environment and genetically determined has oriented research towards "internal" and deterministic components of development, and this implicit assumption led to neglect other, potentially crucial, interactions with "external" factors (Gilbert and Bolker 2003; Sultan 2015), such as temperature, predators, symbionts 
(Gilbert and Epel 2009), or stochastic processes such as developmental noise (Lewontin 2000) and somatic mutations during normal development (Campbell et al. 2015).

For example, it has been widely assumed that the way immune systems develop and enable hosts to resist diseases was to a large extent dependent on genetic factors. Now, in a striking recent study on human monozygotic and dizygotic twins, Mark Davis' group at Stanford showed that environmental effects are much more important than genetic factors in determining how the adaptive immune system develops and makes the organism resistant to diseases (Brodin et al. 2015). Because of an unquestioned conviction that genes played a major role in the development of the immune system, these environmental factors (especially previous microbial exposures, vaccinations, diet, and dental hygiene) had not been thoroughly investigated.

Importantly, the neglect of environmental factors is to some extent related to the choice of model organisms. Many "classic" model organisms in developmental biology were chosen in part because they were relatively robust under environmental perturbation (Bolker 1995). In turn, results obtained in these models have tended to reinforce the view that all development is regulated from inside the egg, and that "outdoor" experiments were unnecessary (Gilbert and Bolker 2003).

Thus, it can be argued that most developmental biologists, even those who say they do not need a definition of development, do in fact have implicit conceptions of development, which can affect their practical research. Having a definition of development can help making explicit these otherwise implicit assumptions, and perhaps overcoming them.

\section{Analysis of a few possible definitions of "development"}

For those who think that defining development is important, an open question is how exactly should the notion of development be defined. Table 1 presents common definitions of development, with their proponents (mostly scientists, though some of them are philosophers or historians), and the potential difficulties they raise.

\begin{tabular}{|c|c|c|}
\hline Definition & Proponents & Possible difficulties \\
\hline $\begin{array}{l}\text { Process through which a single cell } \\
\text { gives rise to a complex } \\
\text { multicellular organism }\end{array}$ & $\begin{array}{l}\text { Barinaga (1994); Coen (1999); } \\
\text { Martinez-Arias and Stewart } \\
\text { (2002); Wolpert and Tickle }(2011)\end{array}$ & $\begin{array}{l}\text { - Excludes several important } \\
\text { developmental processes, e.g., } \\
\text { regeneration } \\
\text { - Excludes many organisms (e.g., } \\
\text { uncellulars), and several forms of } \\
\text { asexual reproduction } \\
\text { - "Adultocentrism" } \\
\text { (on these three aspects, see Minelli } \\
\text { 2003) }\end{array}$ \\
\hline $\begin{array}{l}\text { Elaboration of a new individual } \\
\text { form }\end{array}$ & $\begin{array}{l}\text { Amundson (1994) } \\
\text { Love (2008) } \\
\text { Pradeu (2014: 15) }\end{array}$ & $\begin{array}{l}\text { - Difficult to define the notions of } \\
\text { "new", "shape" or "form" }\end{array}$ \\
\hline $\begin{array}{l}\text { Change of biological form through } \\
\text { time }\end{array}$ & Slack (2013: 3) & $\begin{array}{l}\text { - Difficult to define "form" } \\
\text { - Difficult to distinguish } \\
\text { development from metabolism }\end{array}$ \\
\hline $\begin{array}{l}\text { Temporal change of organization } \\
\text { along the life cycle }\end{array}$ & $\begin{array}{l}\text { Waddington (1956: 3); Oyama } \\
\text { (2000); Oyama, Griffiths and Gray } \\
(2001) \text {; Minelli (2003); West- } \\
\text { Eberhard (2003: 32); Gilbert } \\
(2013)\end{array}$ & $\begin{array}{l}\text { - Difficult to define "organization" } \\
\text { - Lacks specificity, as it includes } \\
\text { too many biological phenomena }\end{array}$ \\
\hline $\begin{array}{l}\text { Biological readout of the } \\
\text { genomically encoded gene } \\
\text { networks that determine how the } \\
\text { organism is constructed }\end{array}$ & $\begin{array}{l}\text { Davidson (2001); } \text { Peter } \quad \text { and } \\
\text { Davidson (2015) }\end{array}$ & $\begin{array}{l}\text { - Ignores the role of other factors } \\
\text { that can control development, such } \\
\text { as hormones, mechanical forces } \\
\text { and environmental factors (Gilbert }\end{array}$ \\
\hline
\end{tabular}




\begin{tabular}{|l|l|l|}
\hline & & $2002)$ \\
\hline $\begin{array}{l}\text { Irreversible increase of complexity } \\
\text { over time }\end{array}$ & Arthur (1997: 277). & $\begin{array}{l}\text { Difficult to define "complexity" } \\
\text { There are cases where } \\
\text { development seems to be } \\
\text { associated with a decrease in } \\
\text { complexity, in particular during } \\
\text { metamorphosis of sessile or } \\
\text { parasitic animals (e.g., ascidians, } \\
\text { Sacculina) }\end{array}$ \\
\hline $\begin{array}{l}\text { Restriction of possible outcomes } \\
\text { (specialization) and increase in } \\
\text { levels of organization. }\end{array}$ & Johnson (2001) & Depends on the level considered \\
\hline
\end{tabular}

Table 1. Some possible definitions of development

Obviously, this table is not exhaustive; our aim is simply to open the discussion about possible definitions, on the basis of suggestions regularly found in the literature. Also, this does not entail that anyone interested in defining the notion of "development" would have to adopt a unique definition; quite the contrary, it is certainly possible to combine several definitions, among those listed here, or others. Because of the relative malleability of the term "development," one interesting possibility could even be to articulate a "cluster" definition of development, with at its core the processes that everyone considers as part of development (e.g., gastrulation in metazoans, or seed germination in spermatophyta), and satellite processes that at least some specialists consider as part of development (e.g., fertilization, regeneration). Further investigations will have to determine whether elaborating such a "cluster" definition is possible, and whether it is considered as useful by a number of practicing developmental biologists.

\section{Conclusion}

So, should developmental biologists care about defining development? Overall, we believe that arguments in favor of a definition of development prevail. First, it is crucial to determine which subjects belong to "developmental biology" and to distinguish this domain from other biological fields. Second, even when people claim to have no definition of development, they have in mind an implicit conception that impacts their research, highlighting the need to make explicit the implicit. Clarifying the meaning of scientific notions can be a remarkable way to reflect on what we hitherto got right or wrong, and therefore decide on where to go in the future.

\section{Acknowledgments}

We thank Paul Wassarman for his invitation to contribute to the present special issue of $C T D B$. We also thank Wallace Arthur, Jean Gayon, Alain Ghysen, Scott Gilbert, Paul Griffiths, Jane Maienschein, Michel Morange, Maureen O’Malley, Susan Oyama, and Karola Stotz for their help.

\section{References}

Amundson, R. (1994). Two Concepts of Constraint: Adaptationism and the Challenge from Developmental Biology. Philosophy of Science, 61(4), 556-578.

Arthur, W. (1997). The Origin of Animal Body Plans. Cambridge University Press, Cambridge.

Baehrecke, E.H. (2002). How death shapes life during development. Nature Reviews Molecular Cell Biology, 3(10), 779-787.

Barinaga, M (1994). Looking to development's future. Science 266: 561-564. 
Birnbaum, K.D. \& Sanchez Alvarado, A. (2008). Slicing across Kingdoms: Regeneration in Plants and Animals. Cell, 132, 697-710.

Bolker, J. (1995). Model systems in developmental biology. Bioessays, 17, 451-455.

Bonner, J.T. (1965). Size and Cycle: An Essay on the Structure of Biology. Princeton University Press, Princeton.

Bonner, J.T. (2009). The Social Amoebae: the Biology of Cellular Slime Molds. Princeton University Press, Princeton.

Brodin, P. et al. (2015). Variation in the Human Immune System Is Largely Driven by NonHeritable Influences. Cell, 160, 37-47.

Burian, R. \& Thieffry, D. (2000). Introduction to the Special Issue 'From Embryology to

Developmental Biology'. History and Philosophy of the Life Sciences, 3, 313-323.

Campbell, I.M., Shaw, C.A., Stankiewicz, P. \& Lupski, J.R. (2015). Somatic mosaicism: implications for disease and transmission genetics. Trends in Genetics, 31, 382-392.

Coen, E. (1999). The Art of Genes. Oxford University Press, Oxford.

Crowe, N. et al. (2015). The diversification of developmental biology. Studies in History and Philosophy of the Biological and Biomedical Sciences, 53, 1-15.

Dalcq, A.M. (1953). Foreword. Journal of Embryology and Experimental Morphology 1(1), $1-4$.

Davidson, E. H. (2001). Genomic Regulatory Systems: Development and Evolution. Academic Press, San Diego.

Dumais, J., Serikawa, K. \& Mandoli, D.F. (2000). Acetabularia: a unicellular model for understanding subcellular localization and morphogenesis during development. Journal of Plant Growth Regulation, 19(3), 253-264.

Fusco, G. \& Minelli, A. (2010). Phenotypic plasticity in development and evolution: facts and concepts. Philosophical Transactions of the Royal Society B: Biological Sciences, 365, 547556.

Gilbert, S.F. (1991). Preface. In Gilbert, S.F. (Ed.), A Conceptual History of Modern Embryology. The Johns Hopkins University Press, Baltimore, p. vii-ix.

Gilbert, S.F. (1998). Conceptual breakthroughs in developmental biology. Journal of Biosciences, 23, 169-76.

Gilbert, S.F. (2002). Book Review: Genomic Regulatory Systems: Development and Evolution. American Journal of Medical Genetics, 108, 341-342.

Gilbert, S.F. (2013). Developmental Biology, Tenth Edition. Sinauer Associates, Sunderland, MA.

Gilbert, S.F. \& Bolker, J.A. (2003). Ecological developmental biology: preface to the symposium. Evolution and Development, 5, 3-8.

Gilbert, S.F. \& Epel, D. (2009). Ecological Developmental Biology. Sinauer Associates, Sunderland, MA. $2^{\text {nd }}$ ed. 2015.

Gottlieb, G. (1992). Individual Development and Evolution: The Genesis of Novel Behavior. Oxford University Press, New York.

Guirao, M. \& Aréchaga, J. (1989). Editorial Statement. A word of welcome - and a changing of the guard. International Journal of Developmental Biology, 33, 1.

Johnson M.H. (2001). Functional Brain Development During Infancy. In Galvin Bremner and Alan Fogel (eds.), Blackwell Handbook of Infant Development, Blackwell, Malden, MA, pp. 169-190.

Keller, E.F. (2002). Making Sense of Life. Harvard University Press, Cambridge.

Kroos, L. \& Maddock, J.R. (2003). Prokaryotic Development: Emerging Insights. Journal of Bacteriology, 185, 1128-1146.

Kuhn, T. (1962). The Structure of Scientific Revolution. University of Chicago Press, Chicago. Lewontin, R. (2000). The Triple Helix. Harvard University Press, Cambridge. 
Love, A.C. (2008). Explaining the ontogeny of form: philosophical issues. In Sarkar, S. and A. Plutynski (Eds.), A Companion to the Philosophy of Biology. Blackwell, Malden, MA, p. 223247.

Love, A.C. \& Travisano, M. (2013). Microbes modeling ontogeny. Biology and Philosophy, 28, 161-188.

Maienschein, J. (2014). Embryos under the Microscope. Harvard University Press, Cambridge. Martinez-Arias, A., and Stewart, A. (2002). Molecular Principles of Animal Development. Oxford University Press, Oxford.

Meyerowitz, E.M. (2002). Plants compared to animals: the broadest comparative study of development. Science, 295, 1482-1485.

Minelli, A. (2003). The Development of Animal Form. Cambridge University Press, Cambridge.

Minelli, A. (2014). Developmental disparity. In Minelli, A., and Pradeu, T. (Eds.), Towards a Theory of Development. Oxford University Press, Oxford, p. 227-245.

Minelli, A. \& Pradeu, T. (2014), Theories of development in biology: problems and perspectives. In Minelli, A., and Pradeu, T. (Eds.), Towards a Theory of Development. Oxford University Press, Oxford, p. 1-15.

O’Malley, M. \& Dupré, J. (2007). Size doesn't matter: towards a more inclusive philosophy of biology. Biology and Philosophy, 22, 155-191.

Oyama, S. (2000 [1985]). The Ontogeny of Information. Duke University Press, Durham.

Oyama, S., Griffiths, P. \& Gray, R., eds. (2001). Cycles of Contingency: Developmental Systems and Evolution. MIT Press, Cambridge.

Peberdy, J.F. (1980). Developmental Microbiology. Wiley, New York.

Peter, I. \& Davidson, E.H. (2015). Genomic Control Process: Development and Evolution. Academic Press, London.

Pradeu, T. et al. (2011). The Boundaries of Development. Biological Theory, 6, 1-3.

Pradeu, T. (2014). Regenerating Theories in Developmental Biology. In Minelli, A., and Pradeu, T. (Eds.), Towards a Theory of Development. Oxford University Press, Oxford, p. 1532.

Rheinberger, H-J. (2000). Gene Concepts: Fragments from the Perspective of Molecular Biology. In Beurton, P., Falk, R., and Rheinberger, H-J. (Eds.), The Concept of the Gene in Development and Evolution. Cambridge University Press, Cambridge, pp. 219-239.

Saunders, J.W. (1966). Death in embryonic systems. Science, 154, 604-612.

Schleiden, M.J. (1848). The Plant: A Biography. Hippolyte Bailliere, London.

Shimkets, L.J. (1999). Intercellular signalling during fruiting-body development of Myxococcus xanthus. Annual Review of Microbiology, 53, 525-549.

Slack, J.M.W. (1991). From Egg to Embryo. $2^{\text {nd }}$ ed. Cambridge University Press, Cambridge.

Slack J.M.W. (2013), Essential Developmental Biology. Blackwell, Malden, MA.

St Johnston, D. (2015). The Renaissance of Developmental Biology. PLoS Biology, 13:e1002149.

Steeves ,T.A. \& Sussex, I.M. (1989). Patterns in Plant Development. Cambridge University Press, Cambridge.

Straight, P.D., \& Kolter, R. (2009). Interspecies Chemical Communication in Bacterial Development. Annual Review of Microbiology, 63, 99-118.

Sultan, S.E. (2015). Organism and Environment: Ecological Development, Niche Construction, and Adaptation. Oxford University Press, Oxford.

Vervoort, M. (2014). Comparison of animal and plant development: a right track to establish a theory of development? In Minelli, A., and Pradeu, T. (Eds.), Towards a Theory of Development. Oxford University Press, Oxford, p. 203-217.

Waddington, C. H. (1956). Principles of Embryology. Macmillan, New York. 
Weiss, P. (1959). Introduction. Developmental Biology, 1(1), 1.

West-Eberhard, M.J. (2003). Developmental Plasticity and Evolution. Oxford University Press, Oxford.

Wolpert, L. (1968). The French flag problem: a contribution to the discussion on pattern development and regulation. In Waddington, C. H. (Ed.), Towards a Theoretical Biology, Vol. 1. Edinburgh University Press, Edinburgh, pp. 125-33.

Wolpert, L. (1994). Do we understand development? Science, 266, 571-572.

Wolpert, L. \& Tickle, C. (2011). Principles of Development. $4^{\text {th }}$ Edition. Oxford University Press, Oxford. 